\title{
TINDAKAN KEPERAWATAN SEBAGAI SALAH SATU FAKTOR RISIKO INFEKSI NOSOKOMIAL DI INSTALASI MEDIKAL DAN SURGIKAL (STUDI DI RSUD ARIFIN ACHMAD PROVINSI RIAU)
}

\author{
Juli Widiyanto \\ Progam Studi D III Keperawatan F-MIPA \& Kesehatan Universitas Muhammadiyah Riau \\ Guru Besar Universitas Diponegoro Semarang \\ Fakultas Kesehatan Masyarakat Universitas Diponegoro Semarang
}

\begin{abstract}
ABSTRAK
Latar Belakang. Infeksi nosokomial adalah indikator tala ukur mutu sebuah rumah sakit.. Penelitian membuktikan bahwa mutu rumah sakit ditentukan oleh faktor pelayanan keperawatan dan sumber daya pelaksana tugas keperawatan. Penelitian ini bertujuan untuk membuktikan tindakan keperawatan mempengaruhi terjadinya infeksi nosokomial di instalasi medikal dan surgikal. Metodologi. Penelitian ini merupakan penelitian observasional dengan rancangan case control. Populasi target adalah semua pasien yang di rawat di rumah sakit. Populasi studi adalah semua pasien yang dirawat di Instalasi Medikal dan Surgikal RSUD Arifin Achmad Propinsi Riau. Pengumpulan data menggunakan quesioner, observasi dan wawancara mendalam. Data dianalisis dengan uji chi-square dan regresi logistik. Hasil. Hasil penelitian menunjukan bahwa memakai APD, menerapkan SOP, cuci tangan sebelum tindakan, dan pengetahuan merupakan faktor yang berhubungan dengan infeksi nosokomial. Tindakan keperawatan yang terbukti berisiko terhadap kejadian infeksi nosokomial adalah tidak cuci tangan sebelum tindakan $(\mathrm{OR}=3,6$; $95 \% \mathrm{CI}=1,3-15,1)$ dan pengetahuan perawat yang rendah $(\mathrm{OR}=3,5 ; 95 \% \mathrm{CI}=1,4-14,8)$, dengan nilai probabilitas sebesar 83\%.Kesimpulan. Berdasar kondisi tersebut disimpulkan bahwa tindakan keperawatan yang merupakan faktor risiko infeksi nosokomial adalah tidak cuci tangan sebelum tindakan dan pengetahuan perawat yang rendah. Disarankan kepada tenaga keperawatan untuk meningkatkan kepatuhan cuci tangan dan pengetahuan tentang infeksi nosokomial.
\end{abstract}

Kata Kunci: Infeksi nosokomial, tindakan keperawatan, Instalasi Medikal dan Surgikal

\section{PENDAHULUAN}

Insiden infeksi nosokomial adalah indikator yang dijadikan tolak ukur mutu sebuah rumah sakit. Semakin tinggi kasus infeksi nosokomial, maka semakin jelek pula mutu pelayanan rumah sakit tersebut. ${ }^{(1)}$

Mutu rumah sakit ditentukan oleh faktor pelayanan keperawatan dan sumber daya pelaksana tugas keperawatan. ${ }^{(2)}$ perlu penanganan secepat mungkin untuk mengatasi penyebab masalah tersebut. ${ }^{(3)}$

Ruang perawatan penyakit dalam, terdapat banyak prosedur dan tindakan yang dilakukan baik untuk membantu diagnosis maupun memonitor perjalanan penyakit dan terapi yang dapat menyebabkan pasien memiliki risiko terkena infeksi nosokomial. Pasien dengan umur tua, berbaring lama, atau beberapa tindakan seperti prosedur diagnostik invasif, pemasangan infus lama dan kateter urin lama, atau pasien dengan penyakit yang memerlukan kemoterapi, penyakit sangat parah, penyakit keganasan, diabetes, anemia, penyakit autoimun dan penggunaan imunosupresan atau steroid memiliki risiko terkena infeksi lebih besar. ${ }^{(4-5)}$

Infeksi nosokomial menyebabkan 16 juta hari ekstra dirawat di rumah sakit (rata-rata 4 hari per infeksi) dan lebih dari 100.000 kematian setiap tahun. Pada tahun 2002, infeksi nosokomial menyebabkan kira-kira 99.000 kematian di Amerika. Di negara-negara berpendapatan rendah dan menengah, infeksi nosokomial memperpanjang lama perawatan di rumah sakit sebesar 5-30 hari. Biaya yang harus dikeluarkan akibat infeksi nosokomial per tahun kira-kira $\$ 7$ miliar di Eropa dan $\$ 6,5$ miliar di Amerika. ${ }^{(6)}$

Laporan Panitia Pengendalian Infeksi (PPI) RSUD Arifin Achmad Propinsi Riau tahun 2010, 
didapatkan $719 \quad(5,08 \%)$ kasus infeksi nosokomial, terdiri atas dekubitus $5,58 \%$, flebitis 4,17\%, Infeksi Luka Operasi (ILO) 0,45\%, pnemonia 3,76\%, sepsis 13,8\%, Infeksi Saluran Kencing (ISK) 2,75\%. Data tahun 2011 periode Januari s/d Juni, terdapat 815 (1,59\%) kasus infeksi nosokomial. Lama perawatan pasien dengan infeksi nosokomial di RSUD Arifin Achmad pada tahun 2010 maupun 2011 cukup bervariasi, antara 14-134 hari. Kasus infeksi nosokomial di RSUD Arifin Achmad mayoritas terjadi di Instalasi Medikal dan Surgikal. Banyaknya kasus infeksi nosokomial di instalasi ini karena banyak kejadian komplikasi penyakit akibat perawatan yang kurang tepat dan instalasi ini memiliki jumlah pasien paling banyak dengan lama hari perawatan melebihi dari batas standar perawatan.

\section{METODOLOGI PENELITIAN}

Penelitian ini merupakan penelitian analitik dengan rancangan case control. Penelitian ini menggunakan pendekatan retrospektif diawali dengan mengamati pada kelompok kasus (infeksi nosokomial), kemudian dilanjutkan dengan kelompok pembanding kontrol (tidak infeksi nosokomial). Setelah mengamati kelompok kasus dan kelompok kontrol, jumlah angka terpajan dan tidak terpajan dari masing-masing kelompok kasus dan kontrol dianalisis dengan membandingkan frekuensi pajanan antara kedua kelompok tersebut. ${ }^{(7-8)}$

Penelitian dilakukan di Instalasi Medikal dan Surgikal RSUD Arifin Achmad Propinsi Riau dari bulan Maret sampai dengan April 2012. Populasi studi pada penelitian ini adalah semua pasien yang dirawat di Instalasi Medikal dan Surgikal RSUD Arifin Achmad Propinsi Riau tahun 2012.

Sampel dalam penelitian ini adalah pasien rawat ianap yang menderita infeksi nosokomial dan tidak infeksi nosokomial di Instalasi Medikal dan Surgikal RSUD Arifin Achmad Propinsi Riau. Besar sampel dalam penelitian ini menggunakan derajat kemaknaan (Confident Interval/CI) $95 \%$, dihitung berdasarkan nilai $\mathrm{OR}$ dan p2 hasil penelitian sebelumnya sesuai dengan sembilan variabel yang diteliti. Besar sampel minimal dihitung menggunakan rumus: ${ }^{(9)}$

$$
n=\frac{\left[Z_{1-\alpha / 2} \sqrt{2 \bar{p}(1-\bar{p})}+Z_{1-\beta} \sqrt{\left(p_{1}\left(1-p_{1}\right)\right)+\left(p_{2}\left(1-p_{2}\right)\right)}\right]^{2}}{\left(p_{1}-p_{2}\right)^{2}}
$$

Diperoleh hasil 25 sampel dengan perbandingan kasus:kontrol $=1: 1$. Pengambilan sampel penelitian menggunakan metode non random baik terhadap sampel kasus maupun sampel kontrol secara purposive sampling, dengan tetap memperhatikan kriteria inklusi dan eksklusi yaitu bukan pasien pindahan dari ICU, Didiagnosis oleh dokter menderita infeksi nosokomial, Pasien berusia 14-60 tahun. Sedangkan kriteria eksklusi adalah Pasien yang keluar dari penelitian setelah ikut serta sebelumnya, Penderita infeksi nosokomial yang telah dinyatakan sembuh dari infeksi nosokomial oleh dokter saat penelitian berlangsung.

Variabel bebas penelitian adalah Pendidikan Perawat, Lama Kerja di ruangan, Pelatihan Infeksi Nosokomial, Memakai APD, Menerapkan SOP, Mencici tangan sebelum tindakan, dan Pengetahuan perawat tentang infeksi nosokomial sedangkan variable terikat adalah kejadian infeksi nosokomial pada pasien rawat inap. Pengumpulan data dilakukan dengan pengisian kuisioner, observasi, dan indepth interview pada perawat.

Pengolahan dan analisis data pada penelitian ini dilakukan menggunakan alat bantu komputer dengan program SPSS for windows release 13.0. data yang dikumpulkan diolah secara univariat untuk melihat deskripsi variabel penelitian, analisis bivariat menggunakan uji statistik chisquare dengan tabel $2 \times 2$ untuk melihat hubungan antara dua variabel penelitian dan analisis Odd Rasio (OR), dan analisis multivariat dengan menggunakan uji regresi logistik berganda untuk mendapatkan model faktor risiko. ${ }^{(10)}$

\section{HASIL DAN PEMBAHASAN}

\section{Gambaran umum responden penelitian}

Distribusi umur perawat di instalasi medikal dan surgikal mayoritas berumur $\leq 30$ Tahun (54\%), dan mayoritas berjenis kelamin perempuan $76 \%$ pada kasus dan $80 \%$ pada kontrol. Gambaran 
variabel penelitian tampak seperti pada tabel berikut:

Tabel 1. Distribusi rangkuman hasil analisis bivariat yang berisiko dan tidak berisiko antara variabel bebas dengan infeksi nosokomial

\begin{tabular}{|c|c|c|c|c|c|}
\hline \multirow[t]{2}{*}{ No } & \multirow[t]{2}{*}{ Tindakan Keperawatan } & \multicolumn{2}{|c|}{ Infeksi Nosokomial } & \multicolumn{2}{|c|}{$\begin{array}{c}\text { Tidak Infeksi } \\
\text { Nosokomial }\end{array}$} \\
\hline & & $\mathbf{n}$ & $\%$ & $\mathrm{n}$ & $\%$ \\
\hline 1 & 2 & 3 & 4 & 5 & 6 \\
\hline 1 & $\begin{array}{l}\text { Pendidikan } \\
\text { Diploma III } \\
\text { Perguruan Tinggi }\end{array}$ & $\begin{array}{c}18 \\
7\end{array}$ & $\begin{array}{l}72 \\
28\end{array}$ & $\begin{array}{c}16 \\
9\end{array}$ & $\begin{array}{l}64 \\
36\end{array}$ \\
\hline 2. & $\begin{array}{r}\text { Lama Kerja } \\
\leq 3 \text { Tahun } \\
\quad>3 \text { Tahun }\end{array}$ & $\begin{array}{l}12 \\
13 \\
\end{array}$ & $\begin{array}{l}48 \\
52 \\
\end{array}$ & $\begin{array}{c}8 \\
17 \\
\end{array}$ & $\begin{array}{l}32 \\
68 \\
\end{array}$ \\
\hline 3. & $\begin{array}{c}\text { Pelatihan Infeksi Nosokomial } \\
\text { Tidak Pelatihan } \\
\text { Pelatihan }\end{array}$ & $\begin{array}{c}20 \\
5\end{array}$ & $\begin{array}{l}80 \\
20\end{array}$ & $\begin{array}{c}18 \\
7\end{array}$ & $\begin{array}{l}72 \\
28\end{array}$ \\
\hline 4. & $\begin{array}{l}\text { Alat Pelindung Diri (APD) } \\
\text { Tidak Memakai APD } \\
\text { Memakai APD }\end{array}$ & $\begin{array}{c}16 \\
9\end{array}$ & $\begin{array}{l}64 \\
36\end{array}$ & $\begin{array}{c}8 \\
17\end{array}$ & $\begin{array}{l}32 \\
86\end{array}$ \\
\hline 5. & $\begin{array}{c}\text { Standar Operasional Prosedur (SOP) } \\
\text { Tidak Menerapkan SOP } \\
\text { Menerapkan SOP } \\
\end{array}$ & $\begin{array}{l}15 \\
10 \\
10\end{array}$ & $\begin{array}{l}60 \\
40\end{array}$ & $\begin{array}{c}7 \\
18 \\
\end{array}$ & $\begin{array}{l}28 \\
72 \\
\end{array}$ \\
\hline 6. & $\begin{array}{c}\text { Cuci Tangan Sebelum Tindakan } \\
\text { Tidak Cuci tangan } \\
\text { Cuci Tangan }\end{array}$ & $\begin{array}{c}16 \\
9\end{array}$ & $\begin{array}{l}64 \\
36\end{array}$ & $\begin{array}{c}7 \\
18\end{array}$ & $\begin{array}{l}28 \\
72\end{array}$ \\
\hline 7. & $\begin{array}{l}\text { Pengetahuan } \\
\text { Pengetahuan Rendah } \\
\text { Pengetahuan Tinggi }\end{array}$ & $\begin{array}{c}17 \\
8\end{array}$ & $\begin{array}{l}68 \\
32\end{array}$ & $\begin{array}{c}8 \\
17\end{array}$ & $\begin{array}{l}32 \\
68\end{array}$ \\
\hline & Total & 25 & 100 & 25 & 100 \\
\hline
\end{tabular}

Berdasarkan tabel 1 tampak bahwa pendidikan responden antara kelompok infeksi nosokomial dan tidak infeksi nosokomial mayoritas lulusan Diploma III yaitu $72 \%$ dan 64\%. Lama kerja perawat mayoritas > 3 tahun yaitu $52 \%$ dan $68 \%$. Pelatihan infeksi nosokomial mayoritas responden tidak pelatihan yaitu $80 \%$ dan $72 \%$. Responden yang memakai alat pelindung diri mayoritas tidak memakai APD pada kelompok infeksi nosokomial yaitu 64\%, sedangkan pada kelompok tidak infeksi nosokomial mayoritas memakai APD yaitu $80 \%$. Standar operasional prosedur pada kelompok infeksi nosokomial mayoritas responden tidak menerapkan SOP yaitu 60\% dan pada kelompok tidak infeksi nosokomial mayoritas menerapkan
SOP yaitu $72 \%$. Responden yang cuci tangan sebelum tindakan pada kelompok infeksi nosokomial mayoritas tidak cuci tangan sebelum tindakan yaitu $64 \%$ dan pada kelompok tidak infeksi nosokomial mayoritas mencuci tangan sebelum tindakan yaitu sebesar $72 \%$. Dan pengetahuan perawat tentang infeksi nosokomial pada kelompok infeksi nosokomial mayoritas berpengetahuan rendah yaitu $68 \%$ sebaliknya pada kelompok tidak infeksi nosokomial mayoritas berpengetahuan tinggi yaitu $68 \%$.

\section{Analisis Bivariat}

Analisi bivariat dimaksudkan untuk mengetahui hubungan antara tindakan keperawatan dengan kejadian infeksi nosokomial.

Tabel 2. Distribusi rangkuman hasil analisis bivariat yang berisiko dan tidak berisiko antara variabel bebas dengan infeksi nosokomial

\begin{tabular}{|c|c|c|c|c|c|c|c|c|}
\hline \multirow{2}{*}{ No } & \multirow{2}{*}{ Tindakan Keperawatan } & \multicolumn{2}{|c|}{ Kasus } & \multicolumn{2}{|c|}{ Kontrol } & \multirow{2}{*}{ OR } & \multirow{2}{*}{$95 \% \mathrm{CI}$} & \multirow{2}{*}{ p-value } \\
\hline & & $\mathrm{n}$ & $\%$ & $\mathrm{n}$ & $\%$ & & & \\
\hline 1 & 2 & 3 & 4 & 5 & 6 & 7 & 8 & 9 \\
\hline 1 & Pendidikan & & & & & & & \\
\hline
\end{tabular}




\begin{tabular}{|c|c|c|c|c|c|c|c|c|}
\hline \multirow{2}{*}{ No } & \multirow{2}{*}{ Tindakan Keperawatan } & \multicolumn{2}{|c|}{ Kasus } & \multicolumn{2}{|c|}{ Kontrol } & \multirow{2}{*}{$\mathbf{O R}$} & \multirow{2}{*}{$95 \% \mathrm{CI}$} & \multirow{2}{*}{ p-value } \\
\hline & & $\mathrm{n}$ & $\%$ & $\mathrm{n}$ & $\%$ & & & \\
\hline & $\begin{array}{ll}- & \text { Diploma III } \\
- & \text { Perguruan Tinggi } \\
\end{array}$ & $\begin{array}{c}18 \\
7\end{array}$ & $\begin{array}{l}72 \\
28\end{array}$ & $\begin{array}{c}16 \\
9\end{array}$ & $\begin{array}{l}64 \\
36 \\
\end{array}$ & 1,4 & $0,4-4,8$ & 0,544 \\
\hline 2. & $\begin{array}{l}\text { Lama Kerja } \\
\bullet \quad \leq 3 \text { Tahun } \\
-\quad>3 \text { Tahun }\end{array}$ & $\begin{array}{l}12 \\
13\end{array}$ & $\begin{array}{l}48 \\
52\end{array}$ & $\begin{array}{c}8 \\
17\end{array}$ & $\begin{array}{l}32 \\
68\end{array}$ & 1,9 & $0,6-6,2$ & 0,248 \\
\hline 3. & $\begin{array}{l}\text { Pelatihan Infeksi Nosokomial } \\
\text { - } \\
\text { - } \\
\text { Tidak Pelatihan } \\
\text { Pelatihan }\end{array}$ & $\begin{array}{c}20 \\
5\end{array}$ & $\begin{array}{l}80 \\
20\end{array}$ & $\begin{array}{c}18 \\
7\end{array}$ & $\begin{array}{l}72 \\
28\end{array}$ & 1,5 & $0,4-5,7$ & 0,508 \\
\hline 4. & \begin{tabular}{l}
\multicolumn{2}{l}{ Alat Pelindung Diri } \\
- \\
- \\
Tidak Memakai APD \\
Memakai APD
\end{tabular} & $\begin{array}{c}16 \\
9\end{array}$ & $\begin{array}{l}64 \\
36\end{array}$ & $\begin{array}{c}8 \\
17\end{array}$ & $\begin{array}{l}32 \\
86\end{array}$ & 3,7 & $1,2-12,2$ & 0,024 \\
\hline 5. & $\begin{array}{l}\text { Standar Operasional Prosedur } \\
\text { - } \\
\text { - } \\
\end{array}$ & $\begin{array}{l}15 \\
10\end{array}$ & $\begin{array}{l}60 \\
40 \\
\end{array}$ & $\begin{array}{c}7 \\
18 \\
\end{array}$ & $\begin{array}{l}28 \\
72\end{array}$ & 3,8 & $1,2-12,6$ & 0,023 \\
\hline 6. & 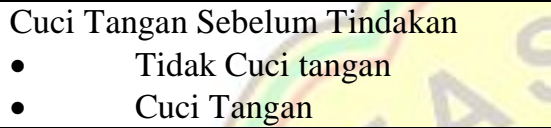 & $\begin{array}{c}16 \\
9\end{array}$ & $\begin{array}{l}64 \\
36\end{array}$ & $\begin{array}{c}7 \\
18\end{array}$ & $\begin{array}{l}28 \\
72\end{array}$ & 4,6 & $1,3-15,1$ & 0,011 \\
\hline 7. & 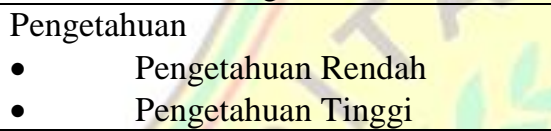 & $8^{17}$ & 32 & $\begin{array}{r}8 \\
17 \\
\end{array}$ & $68^{32}$ & 4,5 & $1,4-14,8$ & 0,011 \\
\hline & Total & 25 & 100 & 25 & 100 & & 20 & \\
\hline
\end{tabular}

Berdasarkan table 2 diketahui bahwa terdapat empat variable yang berhubungan dengan kejadian infeksi nosokomial antara laintidak memakai Alat pelindung diri $(\mathrm{p}=0,024)$ dan OR:3,37,tidak menerapkan standar operasional prosedur $(\mathrm{p}=0,023)$ dan OR: 3,8 , tidak Cuci tangan sebelum tindakan (p-0,011) dan OR:4,6, dan pengetahuan perawat yang rendah $(\mathrm{p}-0,011)$ dan OR: 4,5. Sedangkan variable yang tidak berhubungan antara lain Pendidikan, lama kerja dan pelatihan infeksi nosokomial

\section{Tabel 3. Variabel penting yang dapat masuk dalam uji Multiple Logistic Regresion}

\begin{tabular}{|c|l|c|c|c|}
\hline No & \multicolumn{1}{|c|}{ Tindakan Keperawatan } & OR & $\mathbf{9 5 \%} \mathbf{C I}$ & p-value \\
\hline $\mathbf{1}$ & \multicolumn{1}{|c}{$\mathbf{2}$} & $\mathbf{3}$ & $\mathbf{4}$ & $\mathbf{5}$ \\
\hline 1. & Alat Pelindung Diri (APD) & 3,7 & $1,2-12,2$ & 0,024 \\
\hline 2. & Standar Operasional Prosedur (SOP) & 3,8 & $1,2-12,6$ & 0,023 \\
\hline 3. & Cuci Tangan Sebelum Tindakan & 4,6 & $1,3-15,1$ & 0,011 \\
\hline 4. & Pengetahuan Perawat & 4,5 & $1,4-14,8$ & 0,011 \\
\hline
\end{tabular}

\section{Analisis Multivariat}

Hasil analisis multivariat pada penelitian ini dengan menggunakan uji regresi logistik berganda menunjukan bahwa dari variabel kandidiat diatas, dianalisis secara bersama-sama terdapat dua variabel yang terbukti berisiko dengan kejadian infeksi nosokomial yaitu variabel tidak cuci tangan sebelum tindakan (OR Adjusted $=3,6 ; 95 \%$ Confidence Interval: $1,03-12,65)$ dan pengetahuan rendah (OR Adjusted $=3,5 ; 95 \%$ Confidence Interval: 1,02 - 12,41). Hasil analisis multivariat selengkapnya seperti pada tabel 4
Hasil penelitian menunjukan bahwa tindakan keperawatan yang terbukti sebagai faktor risiko infeksi nosokomial adalah cuci tangan sebelum tindakan ( $p$-value $=0,011)$ dengan nilai $\mathrm{OR}$ Adjudted yang diperoleh 3,6 lebih rendah dari OR bivariat $(4,6) ; 96 \% \mathrm{CI}=1,02-12,65$. Nilai $\mathrm{OR}>$ 1 menunjukan bahwa cuci tangan sebagai faktor risiko infeksi nosokomial yaitu bahwa tidak mencuci tangan sebelum tindakan keperawatan berisiko terjadinya infeksi nosokomial 3,6 kali lebih besar daripada mencuci tangan sebelum tindakan. Hasil penelitian ini konsisten dengan 
penelitian sebelumnya yaitu cuci tangan erat kaitannya dengan kejadian infeksi nosokomial karena cuci tangan berkorelasi dengan perpindahan kuman dari seseorang ke orang lain. (11)

Tangan merupakan bagian tubuh yang lembab yang paling sering kontak dengan kuman yang menyebabkan penyakit dan menyebar. Cara terbaik untuk mencegahnya adalah dengan membiasakan mencuci tangan pada air yang mengalir dengan memakai sabun, Mencuci tangan adalah teknik yang sangat mendasar dalam mencegah dan mengendalikan infeksi, dengan mencuci tangan dapat menghilangkan sebagian besar mikroorganisme yang ada di kulit. ${ }^{(12)}$ Berdasarkan hasil observasi tampak bahwa tempat cuci tangan di ruangan masih sangat terbatas dan hanya di jumpai 2 tempat cuci tangan yaitu di ruang nurse station dan ruang peralatan. Keterbatasan sarana tempat cuci tangan menyebabkan perawat tidak mencuci tangan sebelum melakukan tindakan keperawatan (64\%) pada kelompok kasus.

Penelitian ini juga sejalan dengan hasil penelitian macDonald yang menyebutkan Kebiasaan cuci tangan pada perawat akan mengurangi risiko transmisi methicillin resisten stafilokokus aureus pada pasien sebagai penyebab infeksi nosokomial, perbandingan antara sebelum cuci tangan dan susudah cuci tangan adalah jika sebelum cuci tangan mencapai $78 \%$ maka sesudah cuci tangan ketika kontak dengan pasien hanya $47 \%$. $^{(13)}$

Hasil penelitian Eldridge, memperkuat hasil penelitian tersebut membuktikan bahwa peningkatan praktek cuci tangan akan mempengaruhi terhadap penurunan kejadian infeksi nosokomial di ruang intensive care unit. ${ }^{(14)}$

Hasil penelitian ini membuktikan bahwa tidak cuci tangan sebelum tindakan berpengaruh besar terhadap kejadian infeksi nosokomial. Kondisi tersebut dipengaruhi oleh kebiasaan dan perilaku perawat terutama terhadap kepatuhan perawat untuk membiasakan cuci tangan sebelum tindakan. Perilaku tersebut didukung oleh kondisi sarana dan prasarana yang ada di ruangan untuk tidak melakukan cuci tangan sebelum tindakan.
Hasil penelitian menunjukan bahwa tindakan keperawatan yang terbukti sebagai faktor risiko infeksi nosokomial adalah pengetahuan perawat tentang infeksi nosokomial $(p$-value $=0,011)$ dengan nilai OR Adjudted yang diperoleh 3,5 lebih rendah dari OR bivariat (4,5);96\% CI $=1,4$ - 14,8. Nilai OR > 1 menunjukan bahwa pengetahuan perawat sebagai faktor risiko infeksi nosokomial yaitu bahwa pengetahuan perawat yang rendah berisiko terjadinya infeksi nosokomial 3,5 kali lebih besar daripada perawat yang memiliki pengetahuan tinggi. Hasil ini konsisten dengan penelitian sebelumnya yaitu pengetahuan seorang perawat erat kaitannya dengan kejadian infeksi nosokomial karena pengetahuan berkorelasi dengan bagaimana seseorang dapat mengendalikan dan mencegah infeksi nosokomial.

Pengetahuan merupakan hasil dari tahu, dan ini terjadi setelah orang melakukan penginderaan terhadap sesuatu objek tertentu. Penginderaan terjadi melalui panca indera manusia, yaitu: indera penglihatan, pendengaran, penciuman, rasa, dan raba. Sebagian besar pengetahuan manusia diperoleh melalui mata dan telinga ${ }^{(15-16)}$

Hasil analisis univariat menunjukan bahwa sebagian besar kelompok kasus (68\%) berpengetahuan rendah. Rendahnya pengetahuan perawat tersebut didukung oleh data yang membuktikan bahwa sebagian besar (80\%) perawat tidak pelatihan infeksi nosokomial.

Hasil penelitian membuktikan bahwa 53\% tenaga yang memiliki pengetahuan dan sikap yang baik akan lebih memiliki respon positif untuk melakukan pencegahan terhadap streptococus dan agen mikroba lain. ${ }^{(17)}$ Hasil penelitian lain membuktikan bahwa $88 \%$ perawat memiliki pengetahuan yang baik tentang pencegahan infeksi nosokomial, hal tersebut disebabkan perawat memiliki tingkat pendidikan yang tinggi dan memiliki banyak pengalaman karena telah lama bekerja dibangsal. ${ }^{(18)}$ pernyataan tersebut juga didukung oleh hasil penelitian Huotari. ${ }^{(19)}$ yang menyatakan bahwa pengetahuan yang rendah tentang SOP pencegahan infeksi nosokomial memiliki risiko 6 kali untuk menyebabkan infeksi nosokomial. 
Probabilitas terjadinya infeksi nosokomial oleh karena kedua faktor tindakan keperawatan yang berisiko tersebut sebesar $83 \%$. Hasil tersebut berarti bahwa kontribusi tindakan keperawatan dipengaruhi oleh perilaku. Oleh karena penularan infeksi nosokomial sebagian besar melalui kontak langsung yang dipengaruhi oleh perilaku yang tidak sehat dari perawat. Hasil penelitian menunjukan bahwa adanya kejadian infeksi nosokomial dipengaruhi oleh kedua faktor tersebut.

Hasil penelitian tersebut dapat dikatakan bahwa pengetahuan perawat yang rendah tentang infeksi nosokomial berpengaruh terhadapak kejadian infeksi nosokomial. Rendahnya pengetahuan perawat tersebut dipengaruhi oleh kondisi perawat yang sebagian besar belum pernah mengikuti pelatihan infeksi nosokomial, dan berdasarkan observasi instalsi medikal dan surgikal tidak memiliki perpustakaan yang dapat menunjang untuk meningkatkan pengetahuan perawat, dan hasil indepth interview salah seorang perawat menyatakan:

\section{KESIMPULAN}

Faktor tindakan keperawatan yang terbukti berpengaruh terhadap kejadian infeksi nosokomial:Tidak cuci tangan sebelum tindakan merupakan faktor risiko terjadinya infeksi nosokomial dan pengetahuan perawat yang rendah tentang infeksi nosokomial merupakan faktor risiko terjadinya infeksi nosokomial.

Berdasarkan simpulan diatas, perlunya adanya upaya perbaikan sarana cuci tangan yang cukup dan standar di setiap ruangan rawat inap baik untuk pengunjung, pasien, terutama perawat, meningkatkan kepatuhan perawat untuk melakukan cuci tangan sebelum tindakan untuk mencegah terjadinya infeksi nosokomial, dan disarankan untuk selalu meningkatkan pengetahuan terutama tentang infeksi nosokomial baik melalui pelatihan, pendidikan baik formal maupun non formal

\section{DAFTAR PUSTAKA}

Hawari, D. (2001). Manajemen stress, cemas dan depresi. Jakarta: Balai Penerbit FK UI.

William LM. Total Quality and Organization Development. Petrick A. Joseph Florida: St. Lucie Press; 1997.
Nasution JD. Analisa mutu pelayanana keperawatan dalam shif kerja di ruang rawat inap rumah sakit haji medan tahun 2002 . 2003.

Kasmad, Sujianto U, Hidayati W. Hubungan Antara Kualitas Perawatan Kateter Dengan Kejadian Infeksi Nosokomial Saluran Kemih. 2007;1.

Anonymus. Preventing Nosocomial Infection. Louisiana; 2002 [cited 201111 Agustus]; Available from: www.oph.dhh.louisiana.gov

Ducel G. Prevention of hospital-acquired infections, A practical guide. 2nd edition ed. New York: World Health Organization. Department of Communicable disease, Surveillance and Response; 2002.

Team CCiSC. Report on the burden of endemic health care-associated infection worldwide. Geneva: World Health Organization2011.

Armenian HK. The Case Control Method: Design and Application. New York: Oxford University Press; 2009.

Gordis L. Epidemiology. 4 ed. Philadelphia London New York: W.B. Saunders Company; 2009.

Lemeshow S, Hosmer DW, Klar J. Adequacy of Sample Size in Health Studies. New York: University of Massacusetts And Stephen K. Lwanga Press; 1997.

Kleinbaum DG, Klein M. Logistic Regression A Self-Learning Text. Second Edition ed. Dietz K, Gail M, Krickeberg K, editors. New York: Springer; 2002.

Lankford MG, Zembower TR, Trick WE, Hacek DM, Noskin GA, Peterson LR. Influence of Role Models and Hospital Design on Hand Hygiene of Health Care Workers. Emerging Infectious Diseases 2003;9(2):217-23.

Al-Wazzan B, Salmeen Y, Al-Amiri E, Abul Aa, Bouhaimed M, Al-Taiar A. Hand Hygiene Practices among Nursing Staff in Public Secondary Care Hospitals in Kuwait: SelfReport and Direct Observation. Med Princ Pract 2011;20:326-31.

Lam BCC, Lee J, Lau YL. Hand Hygiene Practices in a Neonatal Intensive Care Unit: A Multimodal Intervention and Impact on Nosocomial Infection. PEDIATRICS 2004;114( 5). 
Eldridge NE, Woods SS, Bonello R, Clutter K, Ellingson L, Harris MA, et al. Using the Six Sigma Process to Implement ttie Centers for Disease Control and Prevention Guideline for Hand Hygiene in 4 Intensive Care Units. J GEN INTERN MED. 2006;21:35-42.

Notoatmodjo S. Pendidikan dan Perilaku Kesehatan. Jakarta: Rineka Cipta; 2009.

Wenzel. Infection control in the hospital,in International society for infectious diseases. second ed. Boston2002.

Beneden CAV, Hicks LA, Riley LE, Schulkin J. Provider Knowledge, Attitudes, and Practices regarding Obstetric and Postsurgical Gynecologic Infections Due to Group A
Streptococcus and Other Infectious Agents. Infectious Diseases in Obstetrics and Gynecology. 2007;2007:1-8.

Habni Y. Perilaku Perawat dalam Pencegahan Infeksi Nosokomial di Ruang Rindu A, Rindu B, ICU, IGD, Rawat Jalan Rumah Sakit Pusat Haji Adam Malik Medan [Penelitian Keperawatan]. Medan: USU; 2009.

Huotari K, Tarkka E, Valtonen V, Kolho E. Incidence and Risk Factors for Nosocomial Infections Caused by FluoroquinoloneResistant Escherichia coli. Eur J Clin Microbiol Infect Dis. 2003;22:492-5 